\title{
Co-circulation of two genotypes of dengue virus serotype 3 in Guangzhou, China, 2009
}

\author{
Tao Jiang ${ }^{1 \dagger}$, Xue-Dong $\mathrm{Yu}^{1+}$, Wen-Xin Hong ${ }^{2 \dagger}$, Wei-Ze Zhou ${ }^{3}$, Man Yu ${ }^{1}$, Yong-Qiang Deng ${ }^{1}$, Shun-Ya Zhu', \\ E-De Qin ${ }^{1}$, Jian Wang ${ }^{2}$, Cheng-Feng Qin ${ }^{1^{*}}$ and Fu-Chun Zhang ${ }^{2^{*}}$
}

\begin{abstract}
Dengue is emerging as the most important mosquito borne viral disease in the world. In mainland China, sporadic and large outbreaks of dengue illness caused by the four serotypes of dengue virus (DENV-1 to DENV-4) have been well documented. Guangdong province is the major affected area in China, and DENV-1 has dominantly circulated in Guangdong for a long time. In this study, a family cluster of DENV-3 infection in Guangzhou was described. Three cases were diagnosed as dengue fever based on clinical manifestation, serological and RT-PCR assays. Two DENV-3 strains were isolated in C6/36 cells and the complete genome sequences were determined. Phylogenetic analysis revealed that the new DENV-3 isolates from the family cluster were grouped within genotype III. Considering the fact that several DENV-3 strains within genotype V were also identified in Guangzhou in 2009, at least two genotypes of DENV-3 co-circulated in Guangzhou. Careful investigation and virological analysis should be warranted in the future.
\end{abstract}

Keywords: Dengue virus type 3, Family cluster, Genotype, Co-circulation

\section{Background}

Dengue is increasing in both frequency and magnitude worldwide, posing a heavy public health and economic burden especially in tropical and subtropical countries. Today, dengue ranks as the most important mosquitoborne viral disease in the world. Annually, up to 50 million human infections occur with 22, 000 deaths mainly in children [1]. Even, population growth, urbanization, international travel, and global warming continuously enhance vector transmission and disease outbreaks [2]. Dengue virus (DENV) contains four serotypes, and each of them can cause a wide spectrum of clinical manifestations, including mild dengue fever (DF), severe dengue haemorrhagic fever (DHF) and deadly dengue shock syndrome (DSS). Although intensive efforts have been made for decades, no preventive vaccines or antiviral drugs is currently available. The pathogenesis of DHF and

\footnotetext{
*Correspondence: qincf@bmi.ac.cn; zfc8y@yahoo.com.cn

${ }^{\dagger}$ Equal contributors

'State Key Laboratory of Pathogen and Biosecurity, Beijing Institute of Microbiology and Epidemiology, No.20 Dongda Street, Fengtai District, Beijing 100071, China

${ }^{2}$ Guangzhou No.8 People's Hospital, Guangzhou Medical College, Guangzhou 510060, China

Full list of author information is available at the end of the article
}

DSS remains poorly understood. However, secondary infection with another DENV serotypes clearly increased the risk of severe diseases via the mechanism of antibody dependent enhancement (ADE) [3-5]. Epidemiological and in vivo data also indicated that antiDENV antibodies mediated pathogenesis of a second heterotypic DENV infection [6-8].

Mainland China has experienced large outbreaks of DF during World War II, after that dengue disappeared for about 30 years. Since 1978, mainland China has seen a resurgence of dengue, epidemics involving hundreds of thousands of people have occurred in many provinces of Southern China, including Hainan, Guangdong, Guangxi, Fujian, Yunnan and Zhejiang provinces [9-14]. Currently, DF is listed as the notifiable infectious disease by the Ministry of Health, China. The recent epidemiology of dengue in China is characterized by a 3-5 year cycle. Most cases are DF, and only a few DHF or DSS cases have been reported over the last decade in mainland China $[9,10,13]$.

In dengue endemic country, the presence of four serotypes of DENV is common, and co-circulation of multiple dengue serotypes in the same area has been well documented [15-17]. Guangdong province has been recognized as the major affected area of China. Although 
all four serotypes of DENV have been isolated in China, the dominant serotype circulating in Guangdong is DENV-1, no other serotypes has been recorded since $2001[9,10,13,18]$. Large DF outbreaks involving more than 1000 cases caused by DENV-1 have been described in Guangdong, China in 2002 and 2006, respectively $[13,19]$.

In this study, we sought to determine the cause of a family cluster of DF in Guangzhou, Guangdong province, China in 2009, and analyze the possible origin of these emerging isolates responsible for the epidemic.

\section{Materials and methods Case description}

On Aug 6, 2009, three adult family members admitted to Guangzhou No.8 People's Hospital as suspected DF cases. The 30-year-old son firstly had a sudden fever with headache, then his father (56-year-old) and mother (50-year-old) fell ill subsequently in the following two days. All the three cases developed typical DF symptoms, including fever, headache, chills, rash, muscle and joint pain, and anorexia. The couples developed diarrhoea, and none of them showed vomiting. The tourniquet tests were all positive. All patients recovered uneventfully and discharged on Aug 11, 2009.

\section{Ethics statement}

The research was approved by the Review Board of Guangzhou No.8 People's Hospital and the Ethical Committee of State Key Laboratory of Pathogen and Biosecurity. Informed consent was obtained from patients.

\section{Serological assay and RT-PCR}

Acute phrase sera were subjected to serological assays using IgM and IgG capture ELISA kit (PanBio, Queensland, Australia) according to the manufacturer's instruction. RTPCR assays were performed to detect and typing of DENVs as previously described [20].

\section{Virus isolation and identification}

Acute phase sera from the three patients were inoculated in C6/36 mosquito cells (Aedesalbopitus clone) and maintained in 1640 medium (Life Technologies, CA, USA) supplement with $2 \%$ fetal bovine serum (Life Technologies) at $28{ }^{\circ} \mathrm{C}$ in $5 \% \mathrm{CO}_{2}$. When complete cytopathic effects $(\mathrm{CPE})$ were observed, culture supernatants from positive samples were collected and stored at $-70{ }^{\circ} \mathrm{C}$ until use. Indirect immunofluscence assay (IFA) was performed as previously described [21].

\section{Sequencing of complete genome of DENV-3 isolates}

The viral RNA was extracted from $200 \mu$ of DENV-3 infected C6/36 culture supernatant using Purelink RNA mini kit (Life Technologies) in accordance with the manufacturer's instructions. A total of 11 overlapping amplicons spanning the complete genomic region were amplified using 11 pairs of primers. The PCR products were sequenced and assembled. The 5' and 3' untranslated regions (UTRs) of viral genome of each isolate were determined using a rapid amplification of either 5' or 3' cDNA ends (RACE) kit (Roche, Mannheim, Germany) followed the manufacturer's recommendation. All primers can be found in Table 1.

\section{Sequence alignment and phylogenetic analysis}

The complete nucleotide sequences of the complete sequences of coding region or envelope $(\mathrm{E})$ gene of global DENV-3 strains were retrieved from GenBank (Table 2). Multiple sequence alignment was carried out employing the CLUSTAL W program [22]. Phylogenetic analyses based on the nucleotide sequence of complete coding region of 44 DENV-3 or complete envelope gene

\section{Table 1 Primers used for sequencing reactions}

\begin{tabular}{|c|c|c|c|}
\hline $\begin{array}{l}\text { Primer } \\
\text { Name }\end{array}$ & Location $^{a}$ & Sequence (5'-3') & $\begin{array}{l}\text { Product } \\
\text { (bp) }\end{array}$ \\
\hline F1 & $1-22$ & AGTTGTTAGTCTACGTGGACCG & 1054 \\
\hline R1 & $1036-1054$ & CGTGGGCTTGTTCTTAGCC & \\
\hline F2 & $857-877$ & GCCCATTACATAGGCACTTCC & 1199 \\
\hline R2 & 2036-2055 & CTTTCCCCAAAAGGAGGTTC & \\
\hline F3 & 1946-1965 & GAGGATGGACAAGGGAAAGC & 1403 \\
\hline R3 & $3326-3348$ & CACCATTCGTGTATCAACTTCCC & \\
\hline $\mathrm{F} 4$ & $3224-3245$ & GGAAAATTGGAGCTGGACTTCA & 1001 \\
\hline R4 & $4206-4224$ & GCCACTAATGGTCCAGCCA & \\
\hline F5 & $4112-4131$ & CTCAAAAGGAGAAGCTGGCC & 1208 \\
\hline R5 & $5299-5319$ & CGCATTGTGAACGTTGCGTG & \\
\hline F6 & $5252-5274$ & GCAACAAAATCTGAACACACAGG & 1071 \\
\hline R6 & $6301-6321$ & GAATAAGTGCGGGCATCAAGC & \\
\hline F7 & $6059-6077$ & AAGTCAGCCGCCATAGACG & 1389 \\
\hline R7 & $7428-7447$ & AGGTGATCCTTCCCAGAGTG & \\
\hline F8 & 7032-7049 & AGGCAGTGGTCCTGATGG & 1143 \\
\hline R8 & $8153-8174$ & GCATTCCTCCATGTTTCCTITG & \\
\hline F9 & $8015-8032$ & TCACCAAGCCCAACAGTG & 1528 \\
\hline R9 & 9520-9542 & TGGCCATTCTIIITAACCTCTCC & \\
\hline F10 & 9270-9293 & AGCTCACATACCAAAACAAAGTGG & 1060 \\
\hline R10 & 10299-10318 & AGCTTCTTCCGTACTGTGGC & \\
\hline $\mathrm{F} 11^{b}$ & 10118-10137 & GGTCTCACTTCCAGAGCAAC & 590 \\
\hline R11 & $10674-10696$ & AGAACCTGTTGATTCAACAGCAC & \\
\hline $\begin{array}{l}5^{\prime} \text { RACE } \\
\text { outer primer }\end{array}$ & $661-678$ & TTGCACGTTCCATAGGTC & \\
\hline $\begin{array}{l}\text { 5'RACE } \\
\text { inner primer }\end{array}$ & $267-284$ & CTGCTGTTGGTGGAATGG & \\
\hline
\end{tabular}

${ }^{a}$ Primer location refers to DENV-3 strain 80-2 [GenBank: AF317645].

${ }^{b}$ Primer F11 was also used as 3'RACE primer. 
Table 2 DENV-3 isolates investigated in this study

\begin{tabular}{|c|c|c|c|c|}
\hline Isolate & $\begin{array}{l}\text { Year of } \\
\text { isolation }\end{array}$ & $\begin{array}{l}\text { Geographical } \\
\text { origin }\end{array}$ & $\begin{array}{l}\text { GenBank } \\
\text { Accession No. }\end{array}$ & Genotype \\
\hline GZ1D3 & 2009 & $\begin{array}{l}\text { China: } \\
\text { Guangdong }\end{array}$ & In this study & III \\
\hline GZ2D3 & 2009 & $\begin{array}{l}\text { China: } \\
\text { Guangdong }\end{array}$ & In this study & III \\
\hline 09/GZ/11144 & 2009 & $\begin{array}{l}\text { China: } \\
\text { Guangdong }\end{array}$ & HM466966 (E) & III \\
\hline 09/GZ/11194 & 2009 & $\begin{array}{l}\text { China: } \\
\text { Guangdong }\end{array}$ & HM466967 (E) & III \\
\hline 09/GZ/13105 & 2009 & $\begin{array}{l}\text { China: } \\
\text { Guangdong }\end{array}$ & HM466968 (E) & III \\
\hline 09/GZ/10616 & 2009 & $\begin{array}{l}\text { China: } \\
\text { Guangdong }\end{array}$ & HM466964 (E) & III \\
\hline Zhejiang/08/09 & 2009 & $\begin{array}{l}\text { China: } \\
\text { Zhejiang }\end{array}$ & GU721065 & III \\
\hline Zhejiang/15/09 & 2009 & $\begin{array}{l}\text { China: } \\
\text { Zhejiang }\end{array}$ & GU721066 & III \\
\hline Zhejiang/17/09 & 2009 & $\begin{array}{l}\text { China: } \\
\text { Zhejiang }\end{array}$ & GU721067 & III \\
\hline Zhejiang/27/09 & 2009 & $\begin{array}{l}\text { China: } \\
\text { Zhejiang }\end{array}$ & GU721068 & III \\
\hline Zhejiang/31/09 & 2009 & $\begin{array}{l}\text { China: } \\
\text { Zhejiang }\end{array}$ & GU721069 & III \\
\hline ZJYW2009 & 2009 & $\begin{array}{l}\text { China: } \\
\text { Zhejiang }\end{array}$ & JF504679 & III \\
\hline 07CHLS001 & 2007 & $\begin{array}{l}\text { China: } \\
\text { Zhejiang }\end{array}$ & EU367962 & $\|$ \\
\hline DTID-ZJU04 & 2009 & $\begin{array}{l}\text { China: } \\
\text { Zhejiang }\end{array}$ & GU189648 & $\|$ \\
\hline 09/GZ/1081 & 2009 & $\begin{array}{l}\text { China: } \\
\text { Guangdong }\end{array}$ & HM466962 (E) & V \\
\hline 09/GZ/1483 & 2009 & $\begin{array}{l}\text { China: } \\
\text { Guangdong }\end{array}$ & HM466963 (E) & V \\
\hline 09/GZ/10806 & 2009 & $\begin{array}{l}\text { China: } \\
\text { Guangdong }\end{array}$ & HM466965 (E) & V \\
\hline $80-2$ & 1980 & $\begin{array}{l}\text { China: } \\
\text { Guangxi }\end{array}$ & AF317645 & V \\
\hline ND143 & 2007 & India & FJ644564 & III \\
\hline DEL-72 & 2008 & India & GQ466079 & III \\
\hline $\begin{array}{l}\text { DENV-3/LK } \\
\text { BID-V2405 }\end{array}$ & 1983 & Sri Lanka & GQ199887 & III \\
\hline $\begin{array}{l}\text { DENV-3/LK } \\
\text { BID-V2409 }\end{array}$ & 1997 & Sri Lanka & GQ252674 & III \\
\hline $\begin{array}{l}\text { DENV-3/MX/ } \\
\text { BID-V2989 }\end{array}$ & 2007 & Mexico & FJ898442 & III \\
\hline $\begin{array}{l}\text { DENV-3/US/ } \\
\text { BID-V2103 }\end{array}$ & 2000 & USA & FJ547071 & III \\
\hline $\begin{array}{l}\text { DENV-3/US/ } \\
\text { BID-V1080 }\end{array}$ & 2006 & USA & EU529699 & III \\
\hline $\begin{array}{l}\text { DENV-3/US/ } \\
\text { BID-V1620 }\end{array}$ & 2005 & USA & FJ182010 & III \\
\hline $\begin{array}{l}\text { DENV-3/US/ } \\
\text { BID-V1090 }\end{array}$ & 1998 & USA & EU529703 & III \\
\hline $\begin{array}{l}\text { DENV-3/US/ } \\
\text { BID-V1043 }\end{array}$ & 2006 & USA & EU482555 & III \\
\hline
\end{tabular}

Table 2 DENV-3 isolates investigated in this study

(Continued)

\begin{tabular}{|c|c|c|c|c|}
\hline $\begin{array}{l}\text { DENV-3NE/ } \\
\text { BID-V2179 }\end{array}$ & 2000 & Venezuela & FJ639750 & III \\
\hline $\begin{array}{l}\text { DENV-3NE/ } \\
\text { BID-V2481 }\end{array}$ & 2007 & Venezuela & GQ868586 & III \\
\hline $\begin{array}{l}\text { DENV-3/NI/ } \\
\text { BID-V2419 }\end{array}$ & 1998 & Nicaragua & GQ199886 & III \\
\hline $\begin{array}{l}\text { DENV-3/NI/ } \\
\text { BID-V2420 }\end{array}$ & 1994 & Nicaragua & FJ882576 & III \\
\hline $\begin{array}{l}\text { DENV-3/NI/ } \\
\text { BID-V2649 }\end{array}$ & 2008 & Nicaragua & FJ873813 & III \\
\hline $\begin{array}{l}\text { DENV-3/NI/ } \\
\text { BID-V4761 }\end{array}$ & 2009 & Nicaragua & HM181972 & III \\
\hline $\begin{array}{l}\text { DENV-3/NI/ } \\
\text { BID-V3055 }\end{array}$ & 2008 & Nicaragua & GQ199860 & III \\
\hline $\begin{array}{l}\text { DENV-3/NI/ } \\
\text { BID-V5498 }\end{array}$ & 2010 & Nicaragua & JF937633 & III \\
\hline $\begin{array}{l}\text { DENV-3/LC/ } \\
\text { BID-V3929 }\end{array}$ & 2001 & Saint Lucia & GQ868616 & III \\
\hline $\begin{array}{l}\text { DENV-3/BR/ } \\
\text { BID-V2400 }\end{array}$ & 2007 & Brazil & FJ850092 & III \\
\hline $\begin{array}{l}\text { DENV-3/BR/ } \\
\text { BID-V2977 }\end{array}$ & 2001 & Brazil & FJ898446 & III \\
\hline $\begin{array}{l}\text { DENV-3/BR/ } \\
\text { BID-V3606 }\end{array}$ & 2007 & Brazil & GU131876 & III \\
\hline $\begin{array}{l}\text { DENV-3/IPC/ } \\
\text { BID-V3832 }\end{array}$ & 2007 & Cambodia & GU131917 & $\|$ \\
\hline $\begin{array}{l}\text { DENV-3/KH/ } \\
\text { BID-V2082 }\end{array}$ & 2003 & Cambodia & FJ639725 & $\|$ \\
\hline $\begin{array}{l}\text { DENV-3/IPC/ } \\
\text { BID-V3820 }\end{array}$ & 2006 & Cambodia & GU131908 & $\|$ \\
\hline $\begin{array}{l}\text { DENV-3/IPC/ } \\
\text { BID-V4286 }\end{array}$ & 2007 & Cambodia & GU131937 & $\|$ \\
\hline $\begin{array}{l}\text { DENV-3/KH/ } \\
\text { BID-V2080 }\end{array}$ & 2003 & Cambodia & FJ639723 & $\|$ \\
\hline $\begin{array}{l}\text { DENV-3/NN/ } \\
\text { BID-V1013 }\end{array}$ & 2006 & Viet Nam & EU482457 & $\|$ \\
\hline $\begin{array}{l}\text { DENV-3/NN/ } \\
\text { BID-V1911 }\end{array}$ & 2008 & Viet Nam & FJ547066 & $\|$ \\
\hline C0360/94 & 1994 & Thailand & AY923865 & $\|$ \\
\hline C0331/94 & 1994 & Thailand & AY876494 & $\|$ \\
\hline $\begin{array}{l}\text { DENV-3/TH/ } \\
\text { BID-V2315 }\end{array}$ & 2001 & Thailand & FJ744729 & $\|$ \\
\hline $\begin{array}{l}\text { DENV-3/TH/ } \\
\text { BID-V3360 }\end{array}$ & 1973 & Thailand & GQ868593 & $\|$ \\
\hline PF90/3050 & 1990 & $\begin{array}{l}\text { French } \\
\text { Polynesia }\end{array}$ & AY744679 & I \\
\hline PF92/4190 & 1992 & $\begin{array}{l}\text { French } \\
\text { Polynesia }\end{array}$ & AY744684 & I \\
\hline den3-88 & 1988 & Indonesia & AY858038 & I \\
\hline FW01 & 2004 & Indonesia & AY858040 & I \\
\hline $\mathrm{H} 87$ & 1956 & Philippines & M93130 & v \\
\hline BS-PRico63 & 1963 & Puerto Rico & AY146762 & IV \\
\hline 1339 & 1977 & Puerto Rico & AY146761 & IV \\
\hline
\end{tabular}


95 DENV-3/LC/BID-V3929/Saint Lucia/2001

DENV-3/US/BID-V1090/USA/1998 DENV-3/NI/BID-V5498/Nicaragua/2010 DENV-3/NI/BID-V3055/Nicaragua/2008

100. DENV-3/NI/BID-V4761/Nicaragua/2009 DENV-3/NI/BID-V2649/Nicaragua/2008 DENV-3/NI/BID-V2420/Nicaragua/1994 - DENV-3/NI/BID-V2419/Nicaragua/1998

98 DENV-3/US/BID-V1620/USA/2005

98 DENV-3/NE/BID-V2481/Nenezuela/2007 DENV-3/VE/BID-V2179/Nenezuela/2000 DENV-3/US/BID-V1080/USA/2006 DENV-3/US/BID-V2103/USA/2000

DENV-3/MX/BID-V2989/Mexico/2007

- DENV-3/LK/BID-V2409/Sri Lanka/1997

ZJYW2009/China/2009

- Zhejiang/08/09/China/2009

- Zhejiang/31/09/China/2009

- Zhejiang/27/09/China/2009

69 Zhejiang/17/09/China/2009

Zhejiang/15/09/China/2009

09/GZ/10616/China/2009

09/GZ/13105/China/2009

४ 09/GZ/11194/China/2009

$10 \mathrm{~b}$

- GZ2D3/China/2009

GZ1D3/China/2009

- 09/GZ/11144/China/2009

ND143/India/2007

$\$ 7$ DEL-72/India/2008

L DENV-3/LK/BID-V2405/Sri Lanka/1983

99 07CHLS001/China/2007

99 DTID-ZJU04/China/2009

99

DENV-3/PC/BID-V3832/Cambodia/2007

DENV-3/KH/BID-V2082/Cambodia/2003

- DENV-3/IPC/BID-V3820/Cambodia/2006

DENV-3/IPC/BID-V4286/Cambodia/2007 - DENV-3/VN/BID-V1013 / Niet Nam/2006

DENV-3/NN/BID-V1911 / Niet Nam/2008

100 C0360/94/Thailand/1994

LENV-3/KH/BID-V2080/Cambodia/2003 DENV-3/TH/BID-V2315/Thailand/2001

30 C0331/94/Thailand/1994

DENV-3/TH/BID-V3360/Thailand/1973

100 PF90/3050/French Polynesia/1990

b0 L PF92 /4190/French Polynesia/1992

_ den3 $88 /$ /ndonesia/1988

99 FW01/Indonesia/2004

96. H87 /Philippines/1956

100

80-2/China/1980

100 09/GZ/1081/China/2009

92 09/GZ/10806/China/2009

92 09/GZ/1483/China/2009

BS-PRico63 /Puerto Rico/1963

$100-1339$ /Puerto Rico/1977

DEN1 WestPac/Nauru/1974 
(See figure on previous page.)

Figure 1 Phylogenetic tree based on the complete envelope gene from 58 DENV-3 strains sampled globally. The evolutionary history was inferred using the neighbor-joining method with MEGA 5 software [24]. Each strain is abbreviated with strain name and country of origin followed by the year of isolation. Bootstrap values greater than 0.9 based on 1000 replicates are shown for key nodes. The tree was rooted using DENV-1 strain Nauru, DENV-2 strain New Guinea C and DENV-4 strain B5 as outgroups. The newly DENV-3 isolates in the study are marked with red squares and other Chinese DENV-3 isolates taken for comparison are marked with blue squares.

of 58 DENV-3 were carried out by Neighbor-Joining method using MEGA version 5.05 or by Bayesian method using BEAST version 1.7.1 [23,24]. The Neighbor-Joining trees were constructed by Tamura-Nei model with gammadistribution of among-site [25]. The Bayesian trees were inferred by Markov Chain Monte Carlo (MCMC) for 5,000,000 generations, sampling at every 100 the generations. Sequences of the DENV-1 strain WestPac [GenBank: U88535], DENV-2 strain NGC [GenBank: AF038403] and DENV-4 strain B5 [GenBank: AF289029] were used as outgroups.

\section{Results}

All three family members were diagnosed as DF according to the new guideline of World Health Organization [26]. Laboratory tests disclosed low WBC and lymphocytes counts for all the three cases. Normal platelet counts were recorded for two cases, while that of the mother was low. None of the patients presented plasma leakage, severe bleeding, or severe organ involvement. All cases recovered in a week post admission.

The acute phase sera from all the three family members were positive for dengue IgM antibody, but negative for IgG antibody. Two of the three cases were positive for DENV-specific RT-PCR. DNA sequencing of the PCR products and blast analysis revealed closely homologous with DENV-3. Considering the fact that DENV3 has not been described in Guangdong for many years, all the three samples were inoculated into C6/36 cells to isolate the viruses. Typical CPE were observed six or seven days post inoculation for two of three samples. After another passage in C6/36 cells, two strains were isolated and named with GZ1D3 and GZ2D3, respectively. Both strains were further confirmed by IFA using dengue specific monoclonal antibody.

Finally, the complete genome sequences of the isolates were determined, assembled and submitted to GenBank [GenBank: GU363549; JN662391]. Both strains were highly homologous $(99.9 \%)$ with only three nucleotide differences. Phylogenetic analysis based on the complete envelope gene classified DENV-3 isolates into five genotypes (Figure 1), which was confirmed by the Bayesian method (Additional file 1: Figure S1). Phylogenetic tree based on the complete sequence of coding region of DENV-3 genome showed the same genotype classification (Figure 2). The newly isolated DENV-3 strains belong to the genotype III, clustering with other DENV3 isolates circulating in China in 2009 and in India in 2007 and 2008 (Figure 1). Interestingly, three additional DENV-3 strains isolated in Guangzhou in 2009 (09/GZ/ 1081, 09GZ/1483 and 09/GZ/10806) [27] belong to genotype V (Figure 1 \& Additional file 1: Figure S1), which indicated that two genotypes of DENV-3 were co-circulating in Guangdong, 2009.

\section{Discussion}

In the present study, a family cluster of DENV-3 infections in Guangzhou, China was described. Three family members were diagnosed as DF, and all recovered finally. All the three family members recalled mosquito biting before illness, and none of them went aboard or on trip recently. Although family cluster of vector-borne diseases have been intensively described [28,29], information regarding DF family cluster is limited. There is no doubt that any cluster of cases is of great concern and should be thoroughly investigated. Dengue can cause both the large epidemics and sporadic infections. The recognition of clustering of disease is important for medical providers and public health personnel in treating and controlling the disease, because multiple infections can occur simultaneously or following an index case. In this study, strict mosquito control measures were initiated immediately after confirmation of the DF cases, and no further cases were reported nearby thereafter.

Whether dengue is endemic in Guangdong remains disputable. Most dengue epidemics in Guangdong were initiated by the introduction of virus from imported cases $[13,18,19,27,30]$, however, in this study none of the family member travelled aboard. Further epidemiology investigation also did not identify imported case nearby either. The origin of these DENV-3 isolate is really interesting. Since DENV-1 has circulated in Guangzhou for about ten years, the new DENV-3 has potential to increase the rate of secondary heterotypic infection. Furthermore, the previous studies showed that epidemic DHF has appeared in association with DENV-3 [31-33]. In the Americas, DENV-3 presented greater epidemic potential and virulence [20]. Whatever, the emerging DENV-3 in Guangzhou might represent a risk factor for severe dengue illness, careful investigation and surveillance should be warranted in the future. 


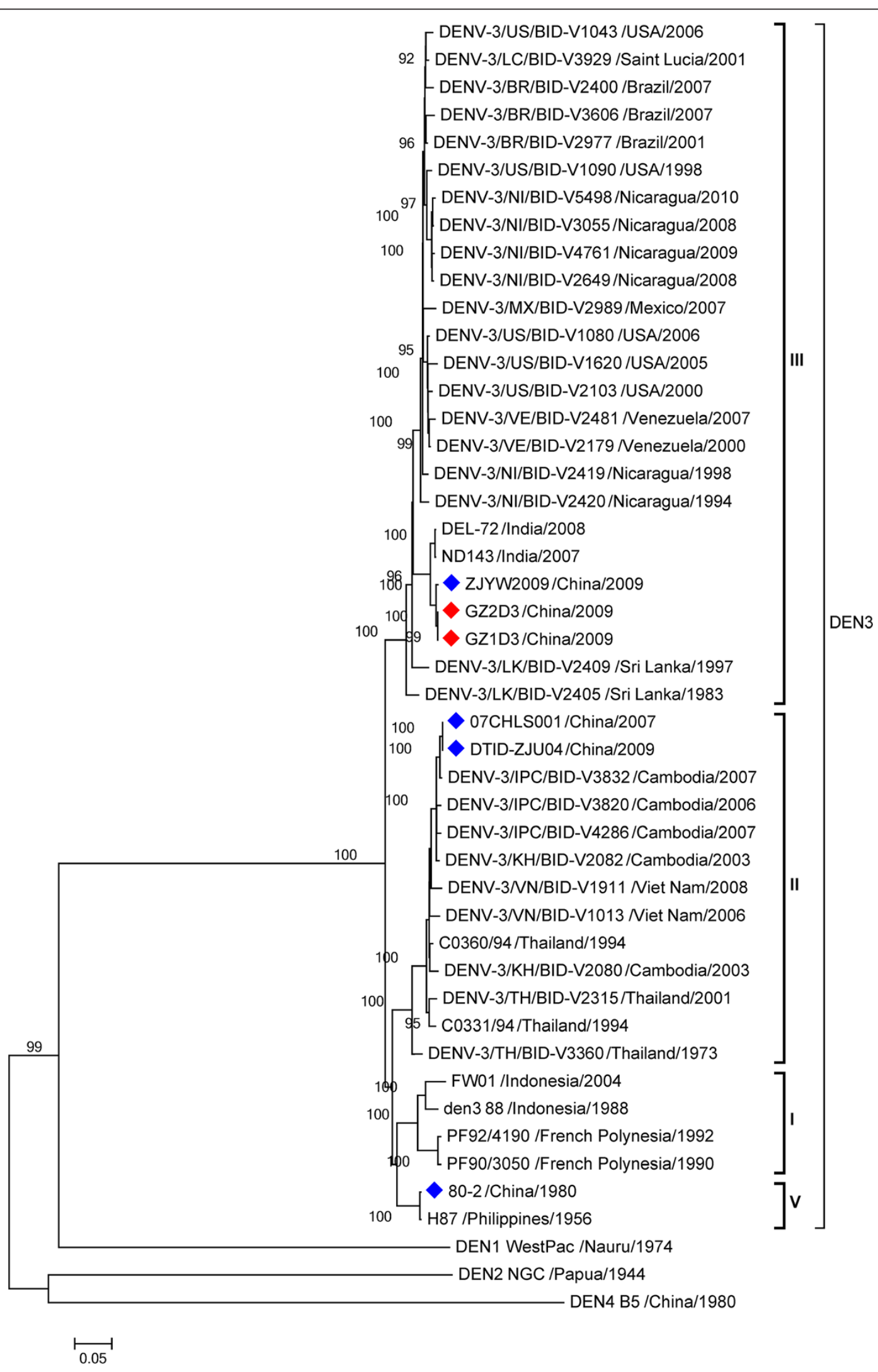

Figure 2 (See legend on next page.) 
(See figure on previous page.)

Figure 2 Phylogenetic tree based on complete sequences of coding region of viral genome from 44 DENV-3 strains sampled globally. The evolutionary history was inferred using the neighbor-joining method with MEGA 5 software [24]. Bootstrap values greater than 0.9 based on 1000 replicates are shown for key nodes. The tree was rooted using DENV-1 strain Nauru, DENV-2 strain New Guinea C and DENV-4 strain B5 as outgroups. The newly DENV-3 isolates in the study are marked with red squares and other Chinese DENV-3 isolates taken for comparison are marked with blue squares.

Most importantly, phylogenetic analysis demonstrated that at least two different genotypes of DENV-3 were cocirculated in Guangdong, China in 2009, which partly agree with the findings of the previous study [27]. Five genotypes of DENV-3 have been reported [20,34]. The newly isolates in Guangdong form a distinct cluster with other Chinese isolates sampled from Zhejiang province in 2009 [35]. All these genotype III DENV-3 strains were closely related to those sampled in India in 2007 and 2008, suggesting these Chinese isolates might be imported from India. Previously, the introduction of new genotype III of DENV-3 has been recognized as one of the factors leading to the emergence of DHF in Pakistan and India [33,36]. These strains are therefore interesting and their virological characterization and virulence analyses are currently underway.

However, three additional DENV-3 strains (09/GZ/1081, 09GZ/1483, and 09/GZ/10806), belonging to genotype V, were also identified in Guangzhou, 2009 in a separate study [27]. In addition, two strains (07CSHL001 and DTIDZJU04) sampled from China, were grouped within genotype II. The origin of these isolates is difficult to determine without further information. The situation that multiple genotypes of DENV-3 co-circulated in Guangzhou, China deserves close concern and careful investigation.

\section{Additional file}

Additional file 1: Figure S1. Phylogenetic tree based on the complete envelope gene from 58 DENV-3 strains by Bayesian method. The evolutionary history was inferred using BEAST 1.7.1 software. The tree was rooted using DENV-1 strain Nauru, DENV-2 strain New Guinea C and DENV-4 strain B5 as outgroups. The newly DENV-3 isolates in the study are marked with red squares and other Chinese DENV-3 isolates taken for comparison are marked with blue squares.

\section{Competing interests}

The authors declare that they have no competing interests.

\section{Authors' contributions}

TJ, XDY, CFQ and FCZ: designed the study, did laboratory testing, analyzed the test results. TJ, EDQ and CFQ co-wrote and edited the manuscript. WXH and WZZ participated in the gene sequencing and phylogenetic analysis. MY, YQD, SYZ, EDQ and JW took samples and did laboratory testing and virus isolation. All authors read and approved the final manuscript.

\section{Acknowledgments}

This study was supported in part by the National Natural Science Foundation of China (No.30972613 and No.81101243), the National 973 Project of China (No.2012CB518904) and the $39^{\text {th }}$ Scientific Research Foundation for the Returned Overseas Chinese Scholars, State Education Ministry. CFQ was supported by Beijing Nova Program of Science and Technology (No.2010B041).

\section{Author details}

${ }^{1}$ State Key Laboratory of Pathogen and Biosecurity, Beijing Institute of Microbiology and Epidemiology, No.20 Dongda Street, Fengtai District, Beijing 100071, China. ${ }^{2}$ Guangzhou No.8 People's Hospital, Guangzhou Medical College, Guangzhou 510060, China. ${ }^{3}$ The Third People's Hospital of Huizhou, Huizhou 516002, China.

Received: 25 November 2011 Accepted: 14 June 2012 Published: 22 June 2012

\section{References}

1. Impact of Dengue. http://www.who.int/csr/disease/dengue/impact/en/.

2. Weaver SC, Reisen WK: Present and future arboviral threats. Antiviral Res 2010, 85:328-345.

3. Fried JR, Gibbons RV, Kalayanarooj S, Thomas SJ, Srikiatkhachorn A, Yoon IK, Jarman RG, Green S, Rothman AL, Cummings DA: Serotype-specific differences in the risk of dengue hemorrhagic fever: an analysis of data collected in Bangkok, Thailand from 1994 to 2006. PLoSNegl Trop Dis 2010, 4:e617.

4. Halstead SB: Neutralization and antibody-dependent enhancement of dengue viruses. Adv Virus Res 2003, 60:421-467.

5. Saito M, Oishi K, Inoue S, Dimaano EM, Alera MT, Robles AM, Estrella BD Jr, Kumatori A, Moji K, Alonzo MT, et al: Association of increased plateletassociated immunoglobulins with thrombocytopenia and the severity of disease in secondary dengue virus infections. ClinExplmmunol 2004, 138:299-303.

6. Dejnirattisai W, Jumnainsong A, Onsirisakul N, Fitton P, Vasanawathana S, Limpitikul W, Puttikhunt C, Edwards C, Duangchinda T, Supasa S, et al: Cross-reacting antibodies enhance dengue virus infection in humans. Science 2010, 328:745-748.

7. Endy TP, Nisalak A, Chunsuttitwat S, Vaughn DW, Green S, Ennis FA, Rothman AL, Libraty DH: Relationship of preexisting dengue virus (DV) neutralizing antibody levels to viremia and severity of disease in a prospective cohort study of DV infection in Thailand. J Infect Dis 2004, 189:990-1000

8. Goncalvez AP, Engle RE, St Claire M, Purcell RH, Lai CJ: Monoclonal antibody-mediated enhancement of dengue virus infection in vitro and in vivo and strategies for prevention. ProcNat/AcadSci U S A 2007, 104:9422-9427.

9. Wu JY, Lun ZR, James AA, Chen XG: Dengue Fever in mainland China. AmJTrop Med Hyg 2010, 83:664-671.

10. Wu W, Bai Z, Zhou H, Tu Z, Fang M, Tang B, Liu J, Liu L, Chen W: Molecular epidemiology of dengue viruses in southern China from 1978 to 2006. Virol J 2011, 8:322.

11. Qiu FX, Gubler DJ, Liu JC, Chen QQ: Dengue in China: a clinical review. Bull World Health Organ 1993, 71:349-359.

12. Li FS, Yang FR, Song JC, Gao H, Tang JQ, Zou CH, Hu BN, Wen SR, Qiu FX: Etiologic and serologic investigations of the 1980 epidemic of dengue fever on Hainan Island, China. AmJTrop Med Hyg 1986, 35:1051-1054.

13. He JF, Luo HM, Liang WJ, Zheng K, Min K, Liu LP: Epidemic situation of dengue fever outbreak in Guangdong province, China, 1990-2005. Dengue Bull 2007, 31:1-9.

14. Wang Q, Xu Z, Dou FM, Zhou H, Wang XF, Yin WW, Li Q: Current situation and surveillance on dengue fever in China, 2005-2007. Zhonghua Liu Xing Bing XueZaZhi 2009, 30:802-806.

15. Bharaj P, Chahar HS, Pandey A, Diddi K, Dar L, Guleria R, Kabra SK, Broor S: Concurrent infections by all four dengue virus serotypes during an outbreak of dengue in 2006 in Delhi. India. Virol J 2008, 5:1. 
16. Holmes EC, Tio PH, Perera D, Muhi J, Cardosa J: Importation and co-circulation of multiple serotypes of dengue virus in Sarawak, Malaysia. Virus Res 2009, 143:1-5.

17. Lorono-Pino MA, Cropp CB, Farfan JA, Vorndam AV, Rodriguez-Angulo EM, Rosado-Paredes EP, Flores-Flores LF, Beaty BJ, Gubler DJ: Common occurrence of concurrent infections by multiple dengue virus serotypes. AmJTrop Med Hyg 1999, 61:725-730.

18. Chen S: The origin of dengue viruses caused the DF outbreak in Guangdong province, China, in 2006. Infect Genet Evol 2011, 11:1183-1187.

19. Zheng K, Zhou HQ, Yan J, Ke CW, Maeda A, Maeda J, Takashima I, Kurane I, $\mathrm{Ma} \mathrm{H}$, Xie XM: Molecular characterization of the $\mathrm{E}$ gene of dengue virus type 1 isolated in Guangdong province, China, in 2006. Epidemiol Infect 2009, 137:73-78.

20. Lanciotti RS, Lewis JG, Gubler DJ, Trent DW: Molecular evolution and epidemiology of dengue-3 viruses. J Gen Virol 1994, 75(Pt 1):65-75.

21. Deng YQ, Dai JX, Ji GH, Jiang T, Wang HJ, Yang HO, Tan WL, Liu R, Yu M, Ge $B X$, et al: A broadly flavivirus cross-neutralizing monoclonal antibody that recognizes a novel epitope within the fusion loop of $E$ protein. PLoS One 2011, 6:e16059.

22. Larkin MA, Blackshields G, Brown NP, Chenna R, McGettigan PA, McWilliam $H$, Valentin F, Wallace IM, Wilm A, Lopez R, et al: Clustal W and Clustal X version 2.0. Bioinformatics 2007, 23:2947-2948.

23. Drummond AJ, Rambaut A: BEAST: Bayesian evolutionary analysis by sampling trees. BMC EvolBiol 2007, 7:214.

24. Tamura K, Peterson D, Peterson N, Stecher G, Nei M, Kumar S: MEGA5: molecular evolutionary genetics analysis using maximum likelihood, evolutionary distance, and maximum parsimony methods. MolBiolEvol 2011, 28:2731-2739

25. Saitou N, Nei M: The neighbor-joining method: a new method for reconstructing phylogenetic trees. MolBiolEvol 1987, 4:406-425.

26. WHO: Dengue - Guidelines for diagnosis, treatment, prevention and control 2009. http://www.who.int/entity/tdr/publications/documents/denguediagnosis.pdf.

27. Di B, Bai ZJ, Wang YL, Luo L, Chen Y, Jiang LY, Yang ZC, Wang M: Molecular epidemiologic analysis on new emerged type 3 dengue virus in Guangzhou in 2009. Zhonghua Liu Xing Bing XueZaZhi 2010, 31:804-807.

28. Papa A, Bino S, Llagami A, Brahimaj B, Papadimitriou E, Pavlidou V, Velo E, Cahani G, Hajdini M, Pilaca A, et al: Crimean-Congo hemorrhagic fever in Albania, 2001. Eur J ClinMicrobiol Infect Dis 2002, 21:603-606.

29. Jones TF, Craig AS, Paddock CD, McKechnie DB, Childs JE, Zaki SR, Schaffner W: Family cluster of Rocky Mountain spotted fever. Clin Infect Dis 1999, 28:853-859.

30. Yang F, Ma SQ, He JF, Mai ZJ, Liang WJ, Cai MX, Luo HM: Epidemiological analysis of imported cases of dengue fever in Guangdong province and Hong Kong during 2004-2006 in China. Zhonghua Liu Xing Bing XueZaZhi 2009, 30:42-44.

31. Briseno-Garcia B, Gomez-Dantes H, Argott-Ramirez E, Montesano R, Vazquez-Martinez AL, Ibanez-Bernal S, Madrigal-Ayala G, Ruiz-Matus C, Flisser A, Tapia-Conyer R: Potential risk for dengue hemorrhagic fever: the isolation of serotype dengue-3 in Mexico. Emerg Infect Dis 1996, 2:133-135

32. Messer WB, Gubler DJ, Harris E, Sivananthan K, de Silva AM: Emergence and global spread of a dengue serotype 3, subtype III virus. Emerg Infect Dis 2003, 9:800-809.

33. Sharma S, Dash PK, Agarwal S, Shukla J, Parida MM, Rao PV: Comparative complete genome analysis of dengue virus type 3 circulating in India between 2003 and 2008. J Gen Virol 2011, 92:1595-1600.

34. Wittke V, Robb TE, Thu HM, Nisalak A, Nimmannitya S, Kalayanrooj S, Vaughn DW, Endy TP, Holmes EC, Aaskov JG: Extinction and rapid emergence of strains of dengue 3 virus during an interepidemic period. Virology 2002, 301:148-156

35. Sun J, Lin J, Yan J, Fan W, Lu L, Lv H, Hou J, Ling F, Fu T, Chen Z, et al: Dengue virus serotype 3 subtype III, Zhejiang Province, China. Emerg Infect Dis 2011, 17:321-323.
36. Khan E, Hasan R, Mehraj V, Nasir A, Siddiqui J, Hewson R: Cocirculations of two genotypes of dengue virus in 2006 out-break of dengue hemorrhagic fever in Karachi, Pakistan. J ClinVirol 2008, 43:176-179.

doi:10.1186/1743-422X-9-125

Cite this article as: Jiang et al:: Co-circulation of two genotypes of dengue virus serotype 3 in Guangzhou, China, 2009. Virology Journal 2012 9:125

\section{Submit your next manuscript to BioMed Central and take full advantage of:}

- Convenient online submission

- Thorough peer review

- No space constraints or color figure charges

- Immediate publication on acceptance

- Inclusion in PubMed, CAS, Scopus and Google Scholar

- Research which is freely available for redistribution 